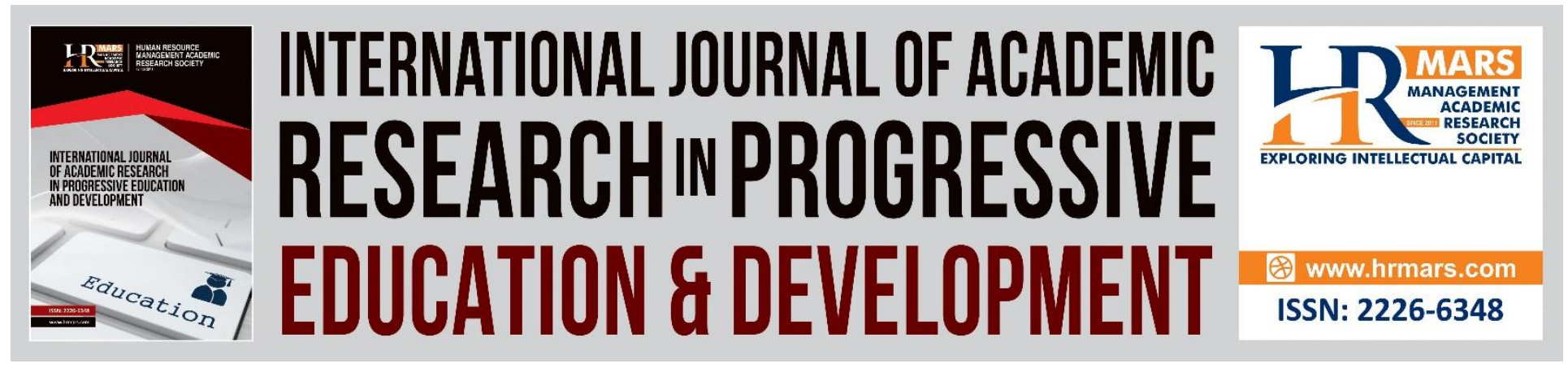

\title{
21st Century Strategy Teaching and Learning (PDPC) in Ibe History Module on Knowledge of Writing Skills for form Six Students
}

Noor Shafinaz Mansor, Nasir Masran

To Link this Article: http://dx.doi.org/10.6007/IJARPED/v10-i2/10004

DOI:10.6007/IJARPED/v10-i2/10004

Received: 02 April 2021, Revised: 26 April 2021, Accepted: 18 May 2021

Published Online: 02 June 2021

In-Text Citation: (Mansor \& Masran, 2021)

To Cite this Article: Mansor, N. S., \& Masran, M. N. (2021). 21st Century Strategy Teaching and Learning (PDPC) in Ibe History Module on Knowledge of Writing Skills for form Six Students. International Journal of Academic Research in Progressive Education and Development, 10(2), 467-473.

Copyright: (C) 2021 The Author(s)

Published by Human Resource Management Academic Research Society (www.hrmars.com)

This article is published under the Creative Commons Attribution (CC BY 4.0) license. Anyone may reproduce, distribute, translate and create derivative works of this article (for both commercial and non-commercial purposes), subject to full attribution to the original publication and authors. The full terms of this license may be seen at: $\underline{\text { http://creativecommons.org/licences/by/4.0/legalcode }}$

Vol. 10 (2) 2021, Pg. 467 - 473

http://hrmars.com/index.php/pages/detail/IJARPED

JOURNAL HOMEPAGE

Full Terms \& Conditions of access and use can be found at http://hrmars.com/index.php/pages/detail/publication-ethics 


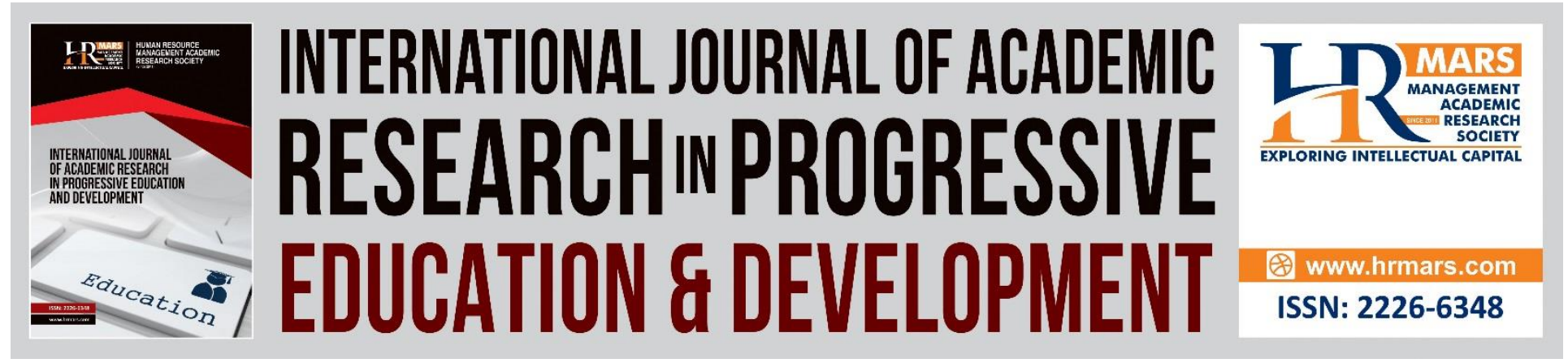

\title{
21st Century Strategy Teaching and Learning (PDPC) in Ibe History Module on Knowledge of Writing Skills for form Six Students
}

\author{
Noor Shafinaz Mansor, MD. Nasir Masran \\ Faculty of Human Development, Universiti Pendidikan Sultan Idris, Tanjong Malim, Perak. \\ Malaysia
}

\begin{abstract}
There are several 21st Century PdPc strategies in the IBE History Module on the knowledge of essay writing skills of Form Six students. Among them are 3 Stray 1 Stay, Gallery Walk and Roundtable. The 21st Century PdPc strategy embedded in the content of this Form Six IBE History Module will help improve the skills of writing a History essay and in turn can improve student achievement in the History Semester 1 examination.

Keywords: 3 Stray 1 Stay, Gallery Walk, Roundtable, IBE History Module, 21st Century PdPc Strategies

\section{Introduction}

This chapter describes the 21st Century PdPc strategy in the IBE History Module on the knowledge of essay writing skills of Form Six students.

\section{1st Century Pdpc Strategy}

Today's education system undergoes holistic innovation and transformation that involves changes to the education system, the quality of school leadership, the quality of teachers, the development of students, as well as the strengthening of more efficient governance (Ahmad, 2015. Every educator needs to make a pradigmic shift and refine their skills and knowledge to face the educational transformation of this century. Benchmarking the quality of national education depends on transformation that has to do with knowledge and information boom. Therefore, educational transformation is a must because the success of economic transformation is highly dependent on the success of futuristic education plans (Mahamod, 2018).

The transformation of the Form Six curriculum began in 2012 with an emphasis on the andragogy approach. Andragogy is the art and science of adult learning, referring to any form of adult learning. Lifelong education has become an educational policy in many countries to enable students to continue to use knowledge, for example the field of science learned and the skills acquired to be applied in their daily lives and professional life later (Nasir, 2017). Therefore, the
\end{abstract}


selection of teaching and learning strategies should be a strategy that can prepare students to address issues, generate ideas, answer questions and solve problems in line with the new Form Six curriculum. As a result, this curriculum prioritizes the andragogical approach that provides lifelong learning opportunities to human capital so that it becomes a living culture in the challenging 21 st century.

The way teachers implement the teaching process influences 21st century learning outcomes. Mastering content standards and learning standards, students' existing knowledge, providing resources and selecting appropriate combinations of strategies and skills should be emphasized by teachers. Teachers should have high competencies in planning and implementing teaching and learning that can meet the educational needs of the 21st century through effective, interesting and interactive pedagogical practices. Furthermore, learning needs to be carried out meaningfully through 'learning by doing' where students are stimulated to think and build their understanding (Norazlin, 2019). Therefore, pedagogy and teaching techniques will facilitate and support students to achieve progress in 21st century learning in the writing of Form Six History essays.

In addition, student achievement is always a measure of the success of the learning process experienced by students in the classroom. This is because PdPc which means a lot helps students increase their interest and motivation to practice lifelong learning. To achieve the country's educational aspirations, the success of teachers is one of the latest transformation shifts. According to Zamri (2012), the form of PdPc in the 21st century is still teacher-centered, but teachers play an important role in actively involving students in learning activities in schools. PdPc through 21st century skills greatly help teachers and students in achieving national educational aspirations. Among the 21st century learning and facilitation strategies (PdPc) used in the Form Six IBE History Module are 3 Stray 1 Stay, Gallery Walk, Jigsaw and Roundtable. All of these strategies can help students master the skills of writing History essays effectively because of the focus of these strategies towards cooperative learning and group discussion. The results of the group discussion through this strategy will eventually improve student achievement in the History Semester 1 examination.

According to Norazlin (2019), pedagogy is the basis for the quality of teaching and learning carried out by teachers and covers principles, techniques and teaching processes. The systematic, interesting and appropriate teaching and learning process is able to motivate students to be actively involved and maintain their motivation throughout the learning activities. At the school level, it requires teachers who have high 21st century teaching and learning practices to develop quality human capital. Therefore, through the teaching and learning practices of the 21st century, teachers who have 21st century pedagogical skills that are aided by the Form Six IBE History Module and diversity in knowledge delivery methodology are important.

Therefore, the application of 21st century skills will be able to help students in facing a life full of globalization challenges with more confidence in the field of education, even in the field of career. Attitudes, motivations and achievements to some extent can encourage students to master 21st century skills more quickly and easily as well as have an impact on History essay writing skills. 


\section{IBE History Module on Knowledge of Essay Writing Skills for Form Six Students}

The effectiveness of teaching History subjects depends on the planning and quality of teaching by teachers (Anuar et al., 2009: Puteh et al., 2010: Deram et al., 2017). Skills in starting classes, questioning techniques and sensitivity to students' existing preparation and knowledge before teaching and during teaching are among the qualities of effective teachers. These aspects can help teachers in holding an effective teaching and learning session and can attract students to follow learning in the classroom (Anuar et al., 2009: Rohani et al., 2010: Deram et al., 2017). Husbands (2011) in Deram (2017) also suggested that teachers need to be skilled in modifying teaching according to the needs and current needs of students. He also stated that many teachers have knowledge of the subject but are not skilled in building students' understanding of the subject of History. Therefore, teachers need to always be prepared in facing the challenges of the educational environment that demands the creativity and competence of teachers.

The effectiveness of the teaching and learning process in the classroom largely depends on the teaching and learning style practiced by teachers. Among the tasks of teachers is to develop teaching and learning strategies that are appropriate for all levels of student learning. In the national education system, several educational innovations are being implemented in schools. One of these innovations is the production of teaching modules. A teaching module is an innovation or printed material that contains suggested activities, methods, presentation styles, procedures and guides to deliver the content to students. It is also equipped with a teaching implementation plan to achieve the learning objectives set within a few hours (Hafizah, 2017). Nurul Hafizah's opinion clearly shows that the use of modules in teaching and learning sessions can facilitate teachers to teach a topic based on activities that have been arranged to achieve learning objectives. The activities found in the module can attract students to deepen their knowledge of a topic as well as improve academic performance.

The module is defined as a teaching and learning activity that is stated according to a set time period. A module is complete for a learning unit. Module teaching and learning provides users with the opportunity to learn in a self-directed, self-access and according to their own abilities (Ismail, 2018). Therefore, with the History essay writing module, students can learn essay writing techniques easily and quickly because in the module has been outlined with procedures or procedures that need to be followed by students. It can improve students' mastery of essay writing techniques. Students can also use this writing module at any time even without the presence of a teacher because this module guides students to learn independently.

A teaching module is a collection of planned and structured learning experiences, usually in the form of self-teaching to achieve the set learning objectives within a few hours or weeks. The use of modules can replace the task of teachers because students can learn on their own according to their abilities and can also be used for remedial purposes (Ismail, 2018). The use of modules in the writing of History essays can help teachers plan the activities to be presented because the activities are organized in the form of self-teaching to achieve learning objectives. The use of modules can reduce competition and the threat of failure. This situation will increase cooperation that students will share the responsibility for learning with teachers (Noah, 2005). As a result, the use of this writing module can replace the teacher's task because students can use the module after completing a topic that has been learned. 
INTERNATIONAL JOURNAL OF ACADEMIC RESEARCH IN PROGRESSIVE EDUCATION AND

DEVELOPMENT

Vol. 10, No. 2, 2021, E-ISSN: 2226-6348 @ 2021 HRMARS

21st Century PdPc Strategy in Form Six IBE History Module

There are three 21st century PdPc strategy activities in the IBE History module namely 3 Stray 1 Stay, Gallery Walk and Roundtable.

\section{Stray 1 Stay}

3 Stray 1 Stay is a PdPc strategy for cooperative learning by further encouraging students to be actively involved in their learning process. This strategy is very much in line with the 21st Century learning approach which emphasizes on the construction of $4 \mathrm{C}$ concepts in PdPc students, namely collaborative, creative, critical thinking and even communication skills. One of the group members will be selected to be a stay (stay in their own group place). The other five members of the group will be stray (moving towards another group) to get information from other groups. Students who become stay have a role to explain and share information from their group to other groups (Masni, 2017). Finally, students are asked to complete the assignment requested by the teacher based on the information obtained from the discussion and implementation of the 3 Stray 1 Stay technique by answering essay questions using the IntroBody Ending (IBE) method which is an essay framework that contains introductions, content and conclusions. Students apply new knowledge by solving problems in new situations using the IBE method to answer essay questions.

\section{Gallery Walk}

Gallery Walk is one of the teaching strategies that is very suitable to be practiced for 21st century learning. This group, as well as student-centered discussion allows students to be actively connected during PdPc sessions. Collaborate in small groups to share ideas and also communicate through questions, documents, pictures, situations and even text. Teachers serve as planners to the implementation of activities by selecting appropriate topics, group divisions and also provide materials that may be used by students. The teacher also serves as a facilitator throughout the activity by providing guidance to the students from each group on what to say in their presentation later. In addition, teachers serve as observers and monitors to ensure that each student is active and learning throughout the presentation period of each group (Masni, 2017). Finally, students are asked to complete the assignment requested by the teacher based on the information obtained as a result of the discussion and implementation of Gallery Walk by answering essay questions using the Intro-Body Ending (IBE) method.

\section{Rountable}

Students are divided into groups of 4 . A piece of paper is distributed to each group. Each member must write a content that is relevant to the topic being discussed. Upon completion, the paper is distributed to the second member. The second member will write the second content. And this will be continued by the next member. Until everything is done. Then each group has to present their collaborative results earlier as a partnership with other groups. They strive to come up with ideas as best they can to help their group complete assignments in advance. They are also more tolerant by helping friends who are having problems in giving interesting ideas. This collaboration helps them among themselves in fostering a good learning environment (Masni, 2017). Finally, students are asked to complete the assignment requested by the teacher based 
on the information obtained as a result of the discussion and implementation of Rountable by answering essay questions using the Intro-Body Ending (IBE) method.

Therefore, a study needs to be done on modular teaching to see the PdPc strategy in the 21st century on the IBE History Module among Form Six students as teaching aids (BBM) teachers and study the level of student achievement in a subject. Teachers need to explore pedagogical knowledge, especially in the use of fuel, such as the construction of the IBE History Module, which is a writing module focused on writing History essays. This is because the use of the module can help students write History essays according to the actual essay writing techniques based on the STPM History Essay Writing Rubric that is knowledge, reasoning and communication (PTK). This PTK will be translated into each part of essay writing which is how to write an introduction, content and conclusion. Through this module, students will be taught how to write a complete History essay based on PTK to get high marks by a teacher or examiner of a History essay paper.

\section{Conclusion}

In conclusion, this study is to look at the extent of 21st Century PdPc strategies in the IBE History Module on the knowledge of essay writing skills and achievement of Form Six students. The study found that teachers as student mentors need to possess and improve the latest skills and knowledge and meet the actual standards related to research. Research that includes action research, empirical research, best practices and other related practices is an approach to improving or enhancing education through change that encourages teachers to be more sensitive, critical, and more aware of their own practices and willing to change practices to a higher level (Kementerian Pendidikan Malaysia, 2018). This noble effort is important to realize the intention of the Ministry of Education Malaysia in the rebranding of Form Six which is to implement changes in teaching and learning to produce quality human capital and able to compete at the national and global levels.

\section{References}

Ahmad, A. (2015). Pengaruh Kompetensi Kemahiran Guru Dalam Pengajaran Terhadap Pencapaian Akademik Pelajar Dalam Mata Pelajaran Sejarah. Bangi: Universiti Kebangsaan Malaysia.

Ahmad, N. L., Sho, S. L., Ab Wahid, H., \& Yusof, R. (2019). Kepentingan amalan pengajaran dan pembelajaran abad 21 terhadap pembangunan pelajar. International Journal of Education, Psychology and Counseling, 28-51. Diperoleh daripada www.ijepc.com.

Deram, S. T. (2017). Pembangunan Modul 5E dalam meningkatkan kemahiran pemikiran sejarah,Universiti Kebangsaan Malaysia : Second International Conference in Education and Regional Development (ICERD 2nd).

Ismail, M. R., Ghazali, A. R., Ab. Latif, K. A., \& Daoh, M. (2018). Ciri-ciri modul kemahiran menulis karangan Bahasa Arab (KMKBA) mengikut keperluan pelajar peringkat universiti di Malaysia, Jurnal Pengajian Islam, 11(1), 15-27.

Kementerian Pendidikan Malaysia. (2018). Jurnal Pendidikan Tingkatan Enam Jilid 2: pengarang. Diperoleh daripada https://www.moe.gov.my/menumedia/media-cetak/penerbitan/jurnal-pendidikantingkatan-enam/1677-jurnal-pendidikan-tingkatan enam-2018-jilid-2/file 
Mahamod, Z. (2017). Pembelajaran abad ke-21 dan pengaruhnya terhadap sikap, motivasi dan pencapaian Bahasa Melayu pelajar sekolah menengah, Universiti Kebangsaan Malaysia : Jurnal Pendidikan Bahasa Melayu - JPBM, Vol. 7, Bil. 2.

Masni, N. H. (2017). Pembinaan modul pembelajaran teradun nutrisi di hujung jari dan kesannya terhadap pencapaian pelajar (Tesis sarjana). Tanjung Malim :Universiti Pendidikan Sultan Idris.

Mutalib, N. A. (2017). Pembelajaran abad ke 21, bukan sekadar susun kerusi dan meja. Kangar :Percetakan Perlis Sdn.Bhd.

Nasir, M., \& Yunus, H. M. (2017). Peranan guru Tingkatan Enam dalam membentuk pelajar terarah kendiri dan meningkatkan kemahiran abad ke-21, Jurnal kurikulum \& Pengajaran Asia Pasifik, 5(1).

Noah, S. M., \& Ahmad, J. (Pnyt.). (2005).Pembinaan modul : Bagaimana membina modul latihan dan modul akademik. Serdang: Universiti Putra Malaysia. 